OPEN ACCESS

Edited by:

Michiko Oyoshi,

Harvard Medical School,

United States

Reviewed by:

Ozge Soyer

Hacettepe University, Turkey

Valerie Verhasselt,

University of Western Australia,

Australia

Cansin Sackesen

Koç University, Turkey

*Correspondence:

Mübeccel Akdis

akdism@siaf.uzh.ch

Specialty section:

This article was submitted to

Immunological Tolerance and

Regulation,

a section of the journal

Frontiers in Immunology

Received: 22 June 2018 Accepted: 29 November 2018 Published: 12 December 2018

Citation:

Satitsuksanoa $P$, Jansen $K$, Gtobińska $A$, van de Veen $W$ and Akdis M (2018) Regulatory Immune Mechanisms in Tolerance to Food Allergy. Front. Immunol. 9:2939. doi: 10.3389/fimmu.2018.02939

\section{Regulatory Immune Mechanisms in Tolerance to Food Allergy}

\author{
Pattraporn Satitsuksanoa, Kirstin Jansen, Anna Głobińska, Willem van de Veen and \\ Mübeccel Akdis *
}

Swiss Institute of Allergy and Asthma Research, University of Zurich, Davos, Switzerland

Oral tolerance can develop after frequent exposure to food allergens. Upon ingestion, food is digested into small protein fragments in the gastrointestinal tract. Small food particles are later absorbed into the human body. Interestingly, some of these ingested food proteins can cause allergic immune responses, which can lead to food allergy. So far it has not been completely elucidated how these proteins become immunogenic and cause food allergies. In contrast, oral tolerance helps to prevent the pathologic reactions against different types of food antigens from animal or plant origin. Tolerance to food is mainly acquired by dendritic cells, epithelial cells in the gut, and the gut microbiome. A subset of $\mathrm{CD} 103^{+}$DCs is capable of inducing T regulatory cells (Treg cells) that express anti-inflammatory cytokines. Anergic T cells also contribute to oral tolerance, by reducing the number of effector cells. Similar to Treg cells, B regulatory cells (Breg cells) suppress effector T cells and contribute to the immune tolerance to food allergens. Furthermore, the human microbiome is an essential mediator in the induction of oral tolerance or food allergy. In this review, we outline the current understanding of regulatory immune mechanisms in oral tolerance. The biological changes reflecting early consequences of immune stimulation with food allergens should provide useful information for the development of novel therapeutic treatments.

Keywords: dendritic cells, food allergy, food microbiome, oral tolerance, regulatory T and B cells

\section{INTRODUCTION}

Food allergy is defined as an adverse immune response to ingested food proteins. This adverse immune response consists of IgE-mediated immediate hypersensitivity reactions, non-IgE-mediated reactions, and disorders with mixed IgE-mediated and cell-mediated immune reactions (Figure 1) (1-4). Food allergy has become an important public health burden in the past few decades, particularly in developed countries (5-7). The prevalence of food allergies is now estimated at $5-10 \%$ of the population in developed countries (8). The prevalence of food-challenge-defined allergies for common food allergens was reported to be: $0.6 \%$ to cow's milk, $0.2 \%$ to egg, $0.1 \%$ to wheat, $0.3 \%$ to soy, $0.2 \%$ to peanut, $0.5 \%$ to tree nuts, $0.1 \%$ to fish, and $0.1 \%$ to shellfish (9). Besides, the World Allergy Organization provided an extensive study using different approaches of food allergy such as oral food challenge, history of the clinical reaction of food-specific IgE, and food allergy questionnaires in 89 member countries. This study revealed that children from Australia, Finland, and Canada at the age of 5 or lower, have the highest prevalence of food allergy (10). The patterns of food allergy were consistent in many regions showing egg and milk were among the most common allergens in preschool children. In other developed countries, the estimation of overall food allergy prevalence has also increased drastically in the past decades for uncertain 


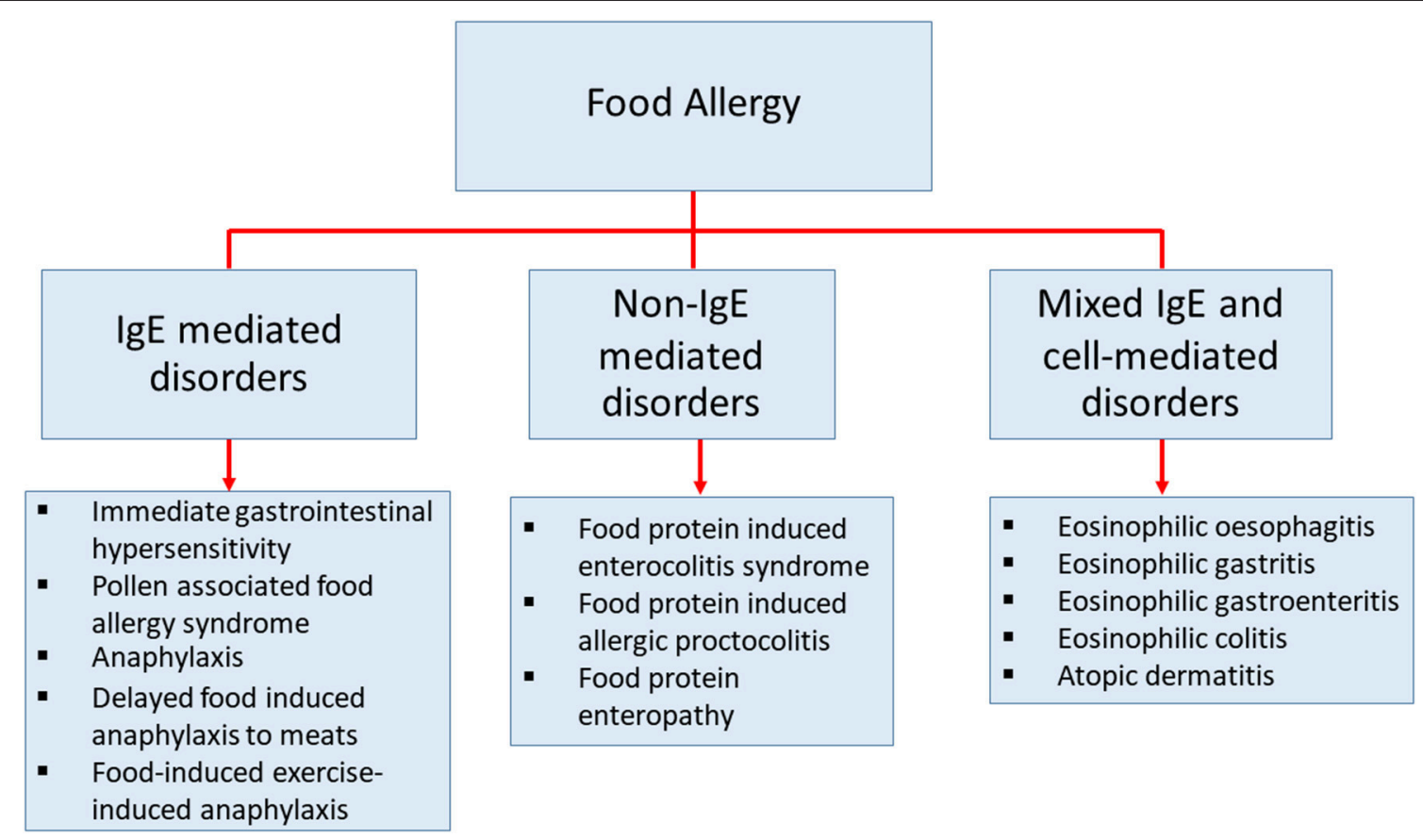

FIGURE 1 | The classification of diseases that cause by food allergy. Classification of food-related diseases by three different immune responses; IgE-mediated immediate disorders, non-IgE-mediated disorders, and disorders with the contributions from mixed IgE-mediated and cell-mediated immune pathways.

reasons $(9,11-14)$. Therefore, to be able to develop more precise diagnostic approaches, prevention, and medical treatments, a better understanding of the mechanisms in food allergy is necessary (15).

\section{INDUCTION OF ALLERGIC IMMUNE RESPONSES}

To know the mechanisms of food allergy, we must understand the role of food allergens in the induction of allergic immune response (16). Food allergens are derived from common naturally-occurring food proteins of plant- and animal-origin $(17,18)$. The proteins in the food are initially broken down by hydrolytic enzymes in the gastrointestinal track during the digestive process. It is hypothesized that food allergens can be modified into different forms and different structures, which can be processed by antigen presenting cells, exhibited on the major histocompatibility complex class II molecules, and subsequently recognized by antigen-specific $\mathrm{T}$ cells (19). The naïve antigenspecific T helper (Th) cells differentiate into effector Th2 cells in the presence of interleukin 4. A set of interleukins such as IL-4, IL-5, IL-10, and IL-13 are massively produced by Th2 cells and induce B cells to differentiate into IgE-producing plasma cells. Antigen-specific IgE antibodies directly bind to high-affinity

Abbreviations: Breg, Regulatory B cell; DC, Dendritic cell; GAP, Gobletcell-associated antigen passages; LAP, Latency-activated peptide; OIT, Oral immunotherapy; OVA, Ovalbumin; SCFA, Short chain fatty acids; Treg, Regulatory T cell. receptor FceRI on mast cells and basophils. During the antigen re-exposure, these specific IgE antibodies induce degranulation of mast cells and release of mediators including cytokines, histamine, and proteases which result in allergic symptoms. There are several factors that influence the allergic responses. For example, boiling or frying peanuts can alter the structure of allergens and reduce their allergenicity. The term "allergenicity" is the ability of allergens to initiate a clinical response through an IgE-mediated mechanism (20). The relative amount of major peanut allergen, Ara h 1 is significantly reduced in fried and boiled food preparations, which results in a drastically decreased IgE-binding intensity. Although Ara h 2 and Ara h 3 showed similar relative amounts in fried, boiled, and roasted peanuts, both allergens had lower IgE-binding capacity in boiled and fried peanuts than in roasted peanuts (21). Similarly heating cow's milk and hen's egg, tends to lower allergenicity (22-24).Cow's milk proteins are considered to be the most common food allergens in IgE- and non-IgE-mediated food allergic disorders in children (25). Most individuals with cow's milk allergy are sensitized to caseins and the whey proteins $\beta$-lactoglobulin and $\alpha$-lactalbumin. Caseins are more resistant to high temperatures compared to whey proteins. Cow's milk allergic children who have a high level of casein IgE are less likely to tolerate a baked milk diet compared to those who have a lower level of casein IgE. Specific IgE-binding patterns to casein and $\beta$-lactoglobulin peptides could predict the original cause of cow's milk allergy and differentiate subjects between the ones who are more likely to outgrow cow's milk allergy at a younger age vs. and the ones who are more likely to develop allergic symptom at a younger age vs. those with a 
more persistent cow's milk allergy (26-28). Besides milk proteins, the two major egg allergens, ovalbumin (OVA), and ovomucoid (Gal d1) are major causes of allergy in children. Bloom et al. showed that Gal d1 has higher heat stability than OVA. OVA showed signs of aggregation after $25 \mathrm{~min}$ of heating while Gal d1 stayed stable up to $60 \mathrm{~min}$. However, both egg allergens showed strongly reduced IgE-binding capacity after thermal processing. Additionally the presence of wheat during the heating process also affects the allergenicity and reduces the IgE binding further (28). In contrast, the effect of heating shellfish results in increased IgE reactivity to crustacean allergens. A recent study confirmed that a higher level of IgE reactivity was observed in cooked crustacean extracts compared to raw extracts (29).

To date, there is no clear answer to the question of "what makes a dietary or digestible protein an allergen?" Besides, the mechanisms of food allergy development have not been comprehensively described. The allergic reactions to food are expected to be enhanced by the imbalance of immune suppression $(30,31)$. As a result of the lack of immune suppression, the induction of immune tolerance to food is not achieved in allergic individuals.

\section{ORAL TOLERANCE}

Oral tolerance is the physiological response to ingested antigens. The development of oral tolerance takes place in the gastrointestinal tract. The gut-associated lymphoid tissues play a major role in limiting inflammatory responses to resident bacteria and food proteins (32). To maintain oral tolerance, the gut-associated lymphoid tissues continue to discriminate self from non-self-antigens and recognize the pathogens that can cause tissue inflammation or gut disease. A breakdown in this process occurs when the gut-associated lymphoid tissues fail to perform its functions. Continuously breaking down of oral tolerance leads to the loss of oral tolerance and unwanted allergic responses. (33). There is an enormous unmet need for modern therapeutic treatments to treat patients with food allergy. Therefore, studies dissecting the mechanisms of oral tolerance are very important (34). The possible mechanisms of oral tolerance may involve recognition of food antigens by dendritic cells, robust induction of Treg cells as well as Breg cells. Also, the environment in human gut reinforces and enhances the expansion of the presence of bacteria-derived metabolites and biogenic amines, such as short-chain fatty acids and histamine (35-38).

\section{Dendritic Cells}

Sensitization to food allergens starts with the uptake of antigens in the gut. This occurs through special types of epithelial cells: $M$ cells $(39,40)$ and more importantly specialized Gobletcells, called goblet-cell-associated antigen passages (GAPs) (41). Antigens, taken up by M cells or GAPs, can then be transferred to dendritic cells (DCs). In the small intestine, there are two major populations of DCs: $\mathrm{CD}_{103}{ }^{+} \mathrm{CX} 3 \mathrm{CR} 1^{-} \mathrm{DCs}$ and CX3CR1+ DCs. CX3CR $1^{+}$DCs are able to directly uptake antigens from the lumen and have more inflammatory potential (42-44). $\mathrm{CD}_{103}{ }^{+} \mathrm{CX} 3 \mathrm{CR} 1^{-}$DCs on the other hand have tolerogenic properties. GAPs exclusively deliver antigens to $\mathrm{CD} 103^{+} \mathrm{CX} 3 \mathrm{CR} 1^{-}$DCs and thus are related to the induction of oral tolerance (41).

Besides GAPs, CXCR1+ macrophages can also present antigens from the lumen to CD103+ DCs and induce tolerogenic effects and IL-10 production. $(45,46)$. After contact with the antigen CD103+CX3CR- DCs can migrate to mesenteric lympnodes in a CCR7 dependent manner (47). In the lympnode $\mathrm{CD}_{103}{ }^{+} \mathrm{CX} 3 \mathrm{CR} 1^{-}$DCs promote the development of $\mathrm{T}$ regulatory cells (Treg cells) through the production of TGF$\beta$ and RALDH2, an enzyme that converts retinol into retinoic acid (48).

\section{T Regulatory Cells}

$\mathrm{T}$ cells play an essential role in food allergies. Th2 cells drive the allergic response by producing IL-4, IL-5, and IL-13. However, other types of $\mathrm{T}$ cells play a role in developing tolerance: Treg cells. There are different types of Treg cells, some are thymusderived and are called natural Treg cells (nTreg cells), and some are induced in the periphery and are called iTreg cells. It was shown by Mucida et al. that oral tolerance can be induced in the absence of thymic-derived Treg cells in a mouse model (49). Besides, Lafaille et al. showed that iTreg cells are essential for establishing oral tolerance (50). The best-described tolerogenic T cells are FOXP3 ${ }^{+}$Treg cells, which are characterized by the expression of CD25 and the transcription factor FOXP3. Treg cells regulate immune responses to allergens through several mechanisms $(51,52)$. Treg cells can produce different types of inhibitory cytokines, such as IL-10 and TGF- $\beta$. Furthermore, they can inhibit antigen-presenting cells by the inhibitory costimulators programmed cell dead protein 1 (PD-1) and cytotoxic T-lymphocyte associated protein 4 (CTLA4). Additionally, Treg cells can prevent the proliferation of effector $\mathrm{T}$ cells through CD25, a high-affinity receptor of IL-2, by depriving the effector cells of IL-2 (53). Lastly, Treg cells can produce granzyme A and B, which can cause cytolysis of effector cells $(54,55)$.

Treg cells play a key role in induction and maintenance of tolerance $(53,56)$. It was shown that FOXP3 knockout mice developed multi-organ inflammatory responses associated with allergic inflammation $(57,58)$. Adoptive transfer of Treg cells was able to suppress anaphylaxis in a food allergy model in mice and was able to control the Th2 immune response (59, 60). It was shown that children with IgE mediated food allergy have significantly lower FOXP3 expression compared to healthy controls $(61,62)$ and children with peanut or egg allergy showed a decrease in Treg cell percentage after allergen exposure (6365). It was also revealed that children with egg allergy have reduced neonatal regulatory $\mathrm{T}$ cell function (66). At last, oral immunotherapy, the only known therapy for food allergies, increases Treg cell function, hypomethylation of FOXP3 gene (67) and the number of FOXP3 positive cells (68). In addition to immunotherapy, low dose IL-2 treatment is also able to induce Treg cells and prevent immune responses (69). A combination of the two treatments has been performed by Smaldini et al. and was effective in reversing IgE-mediated food allergy (70).

Besides conventional FOXP3 ${ }^{+}$Treg cells, another type of Tcell that plays a role in oral tolerance is a Th3 cell. Th3 cells 
do not express FOXP3 or CD25 but express latency-activated peptide (LAP) on their surface, and they are able to produce the inhibitory cytokine TGF- $\beta$. It was shown in mice that epicutaneous immunotherapy with OVA-induced Th3 cells that protected against anaphylaxis by suppressing mast cell activation through TGF- $\beta$ production (71). In an OIT model of cow's milk allergy, fructo-oligosaccharides induced Th3 cells that coincided with protection against anaphylaxis (72). Moreover, Th3 cells were found capable of promoting the development of iTreg cells (73).

TGF- $\beta$ is not only produced by Th3 cells, but also by conventional FOXP3+ Treg that express LAP and the surface molecule GARP (74). Treg cell expression of GARP is essential for optimal induction of oral tolerance (75). IL-6, IL-21, and IL35 can inhibit the expression of GARP on FOXP3+ Treg- cells and thereby inhibit LAP and TGF- $\beta$. Blocking the IL- 6 pathway can enhance oral tolerance in mice (76). Excessive levels of IL4 also inhibited the induction of allergen-specific Treg cells and caused intestinal inflammation in a mouse model (77).

As mentioned earlier CD103+ DCs produce retinoic acid that is able to amplify TGF- $\beta$ production and induce FOXP3+ Treg cells (48). Additionally, retinoic acid produced by DCs induces the expression of receptors $\alpha 4 \beta 7$ and CCR9 on T cells. These receptors are responsible for $\mathrm{T}$ cell homing to the gut (78). It was demonstrated by Hadis et al. that gut-homing and expansion of Treg cells in the lamina propria is necessary to achieve oral tolerance (46). Furthermore, it was shown that homing of IL-10 producing Tregs is important for oral tolerance $(79,80)$.

Besides the functioning of Treg cells, $\mathrm{T}$ cell depletion and anergy can also contribute to oral tolerance. During high dose oral allergen desensitization in cow's milk allergy, a reduction in antigen-specific $\mathrm{T}$ cells was observed (81). Additionally, after it was found that during peanut immunotherapy allergen-specific CD4+ T cells can shift toward an anergic Th2 phenotype (82).

\section{B Regulatory Cells}

B cells that can differentiate into antibody-secreting plasma cells are commonly considered to administer immune responses by producing antigen-specific antibodies and help to induce optimal $\mathrm{CD}^{+}{ }^{+} \mathrm{T}$ cell activation (83). Immunosuppressive Breg cells play a role in the regulation of immune responses by suppressing effector $\mathrm{T}$ cells through the production of suppressor cytokines (IL-10, TGF- $\beta$, and IL-35) (84). However, the role of Breg cells in oral tolerance remains unclear.

Breg cells moderate immune responses in infection, allergic inflammation, and tolerance, predominantly via IL-10 (85). Van de Veen et al. found that inducible IL-10 secreting B regulatory $(\mathrm{Br} 1)$ cells contribute to peripheral allergen tolerance in beekeepers. The increment of bee venom allergen-specific, IL-10-producing B cells, has been observed in bee venom allergic patients receiving AIT. Also, Br1 cells produce IgG4 when they switch to plasma cells, which is a non-inflammatory immunoglobulin isotype that prevents IgE-mediated mast cell and basophil degranulation (86). Allergen-specific IgG4 may be involved in promoting immune tolerance in OIT. Santos et al. demonstrated that the ratio of peanut-specific IgG4 to peanut-specific IgE was higher in tolerant patients compared to peanut-allergic patients (87). The essential mechanism of tolerance induction via IL-10-producing B cells was examined with IL-10-overexpressing B cells. IL-10-overexpressing B cells were found to suppress the maturation of dendritic cells, $\mathrm{T}$ effector cell proliferation, and IgE production. In addition, IL10-overexpressing $\mathrm{B}$ cells produced the anti-inflammatory IL1 receptor antagonist and vascular endothelial growth factor and had lower production of pro-inflammatory cytokines (88). Human type 3 innate lymphoid cells (ILC3s) support the maintenance of mucosal tolerance. A recent study showed that human $\mathrm{CD}_{40 \mathrm{~L}^{+}}$ILC3s provide innate B-cell help and are affected in an innate immunoregulatory mechanism through induction of immature translational Breg cell differentiation, which takes place in palatine tonsils in vivo (89).

IL-10-producing $\mathrm{CD}^{+}$Breg cells in mesenteric lymph nodes play a role in the regulation of IgE-mediated anaphylaxis following challenge with cow's milk allergens in a murine model (90). Peanut-specific B cells were increased in the blood after oral immunotherapy in peanut allergic patients $(91,92)$. A recent study showed IL-10 producing B cells are able to induce and maintain Treg cells in rheumatoid arthritis disease (93). The down-regulation of IL-4, and upregulation of IL-10 production result in an increase of IgG4 and a decrease of IgE levels. IL10 is known to promote heavy chain immunoglobulin isotype switching to IgG4 while IL-4 induces switching to $\operatorname{IgE}(94)$. Furthermore, mucosal IgA inhibits uptake of an antigen by the epithelium and may protect against food allergy (95). The proposed mechanisms of food tolerance are shown in Figure 2.

\section{Gut Microbiome}

The gut microbiome is being increasingly recognized as a major factor in mediating health and disease $(96,97)$. There are several studies describing the interrelation between microbiota of the gastrointestinal tract, respiratory tract, and skin allergic disorders (98-102). Additionally, it has been shown that the microbiome is associated with oral tolerance (103-105). The human microbiome is capable of inducing Treg cells that suppress Th2-derived responses.

Certain bacterial strains such as Bifidobacterium longum 35624, Clostridia, and Bacteroides fragilis can induce intestinal Treg cells that are able to suppress food allergy and colitis $(106,107)$. Pattern-recognition receptor activation on DCs is a potential mechanism by which intestinal microbes (Lactobacillus rhamnosus JB-1) may promote Treg cell differentiation (108). A study from the National Institutes of Health, Human Microbiome Project revealed 14 important bacterial strains by sequencing and analytical processing 380 whole-genome shotgun samples (109). In addition, a $16 \mathrm{~S}$ rDNA gene was sequenced to characterize the oral bacterial composition in saliva samples from healthy and allergic children up to 7 years of age. The result affirmed that early changes in oral microbial composition seem to influence immune maturation and allergy development $(110,111)$.

The potential role of the gut microbiome in food allergy has been studied in mouse models. Rodriguez et al. demonstrated that intestinal colonization of Staphylococcus protects against oral sensitization and allergic response in a mouse model. 


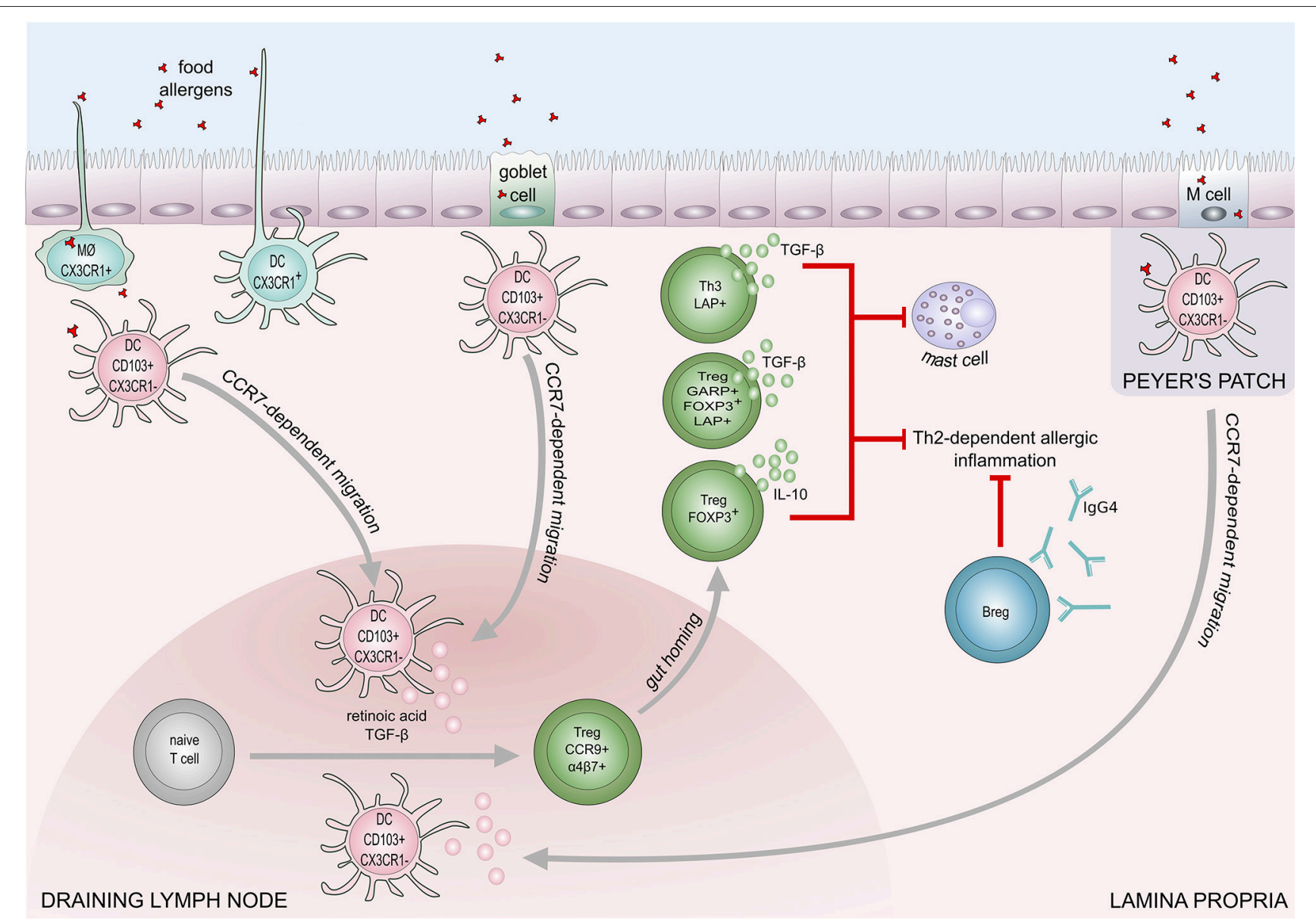

FIGURE 2 | Mechanisms of immune tolerance to food allergens. Induction of food tolerance takes place in the gut when the immune cells encounter food antigens. Several cell types are involved in the antigen uptake: goblet cells, microfold (M) cells, intestinal epithelial cells, CX3CR1+ macrophages (MØ), and CX3CR1+dendritic cells. $\mathrm{CX} 3 \mathrm{CR} 1{ }^{+} \mathrm{DCs}$ and $\mathrm{CX} 3 \mathrm{CR} 1{ }^{+} \mathrm{M} \varnothing$, are capable of extending dendrites to capture antigens on the apical layer of epithelium in the gut lumen. Antigens taken up by $\mathrm{CX} 3 \mathrm{CR} 1^{+} \mathrm{M} \varnothing$ and goblet cells are transferred to $\mathrm{CD} 103^{+} \mathrm{CX} 3 \mathrm{CR} 1^{-} \mathrm{DCs}$, which subsequently migrate to draining lymph node in a CCR7 dependent manner. Production of retinoic acid and TGF- $\beta$ foster differentiation of naïve T cells into regulatory $T$ cells (Tregs). Retinoid acid-dependent induction of integrin $\alpha 4 \beta 7$ expression on Tregs is responsible for T cell homing to lamina propria. Tregs (Foxp3 ${ }^{+}$), and Th3 cells inhibit Th2-dependent allergic inflammation and mast cell degranulation, through the production of IL-10 and TGF- $\beta$. Suppression of Th2-responses also engages regulatory B cells (Bregs) that contribute to food tolerance by producing IgG4.

This was the first study to describe a relationship between alterations within the subdominant microbiota and severity of food allergy (112). Another study showed that allergen-sensitized $\left(\mathrm{Il} 4 \mathrm{ra}^{\mathrm{F} 709}\right)$ mice had a different microbial composition compared to wildtype mice with an increased abundance of different bacterial families including Lachnospiraceae, Lactobacillaceae, Rikenellaceae, and Porphyromonadaceae. This different microbial composition increased OVA-specific responses and anaphylaxis when reconstituted in wild-type germ-free mice, which indicates that the microbial composition play a role in food allergy (113).

Rivas et al. demonstrated that disease-susceptible (Il4ra ${ }^{\mathrm{F} 709}$ ) mice with an enhanced interleukin-4 receptor (IL-4R) signaling exhibited STAT6-dependent impaired generation and function of mucosal allergen-specific Treg cells. Their study showed that the Treg cells failed to suppress mast cell activation and expansion (114). Those Treg cells were reprogrammed into Th2-like cells and participated in the development of food allergy (115). Another study determined that microbiota regulates Th2 responses through the induction of ROR $\gamma \mathrm{t}$ Treg cells and Th17 cells (116).

Moreover, the bacterial metabolites, such as short-chain fatty acids (SCFA's) and biogenic amines produced in the human gut play a role in host immune regulatory activity $(117,118)$. SCFA'sare able to enhance dendritic cell regulatory activity, leading to the induction of Treg cells and IL-10-secreting T cells (119). SCFA's can be produced by bacteria after digestion of dietary fibers. It was shown that infants with a diet consisting of high levels of fruits and vegetables is associated with less food allergy by the age of 2 years, which could be due to an increased amount of dietary fiber intake (120). It was shown in mice that deficiency of dietary fiber intake increases the susceptibility to 
OVA induced allergic airway inflammation (121). Additionally, it was shown that uptake of polyunsaturated fatty acids can increase the production of SCFA's by bacteria (122) and the dietary intake of poly unsaturated fatty acids was inversely associated with atopy in childhood (123).

The secretion of biogenic amines such as histamine has extensive effects on many immune cell types $(124,125)$. Histamine levels are increased in patients with irritable bowel syndrome, inflammatory bowel disease and in adult asthma patients $(126,127)$.

Food allergy could be related to changes in microbial exposure in early life, which affect host microbiota composition, modifies the development of host immunity, and causes pathogenic immune responses to food allergens (96). How the microbiome exactly affects food allergy should be further investigated.

\section{CONCLUSION}

Loss of oral tolerance can lead to the development of food allergy in children and adults. However, the development of food allergy in terms of molecular and cellular mechanisms has not yet been demonstrated. The induction or loss of oral tolerance is likely

\section{REFERENCES}

1. Tordesillas L, Berin MC, Sampson HA. Immunology of food allergy. Immunity (2017) 47:32-50. doi: 10.1016/j.immuni.2017.07.004

2. Carter CA, Frischmeyer-Guerrerio PA. The genetics of food allergy. Curr Allergy Asthma Rep. (2018) 18:2. doi: 10.1007/s11882-018-0756-z

3. Boyce JA, Assa'ad A, Burks AW, Jones SM, Sampson HA, Wood RA, et al. Guidelines for the diagnosis and management of food allergy in the United States: summary of the NIAID-sponsored expert panel report. $J$ Allergy Clin Immunol. (2010) 126:1105-18. doi: 10.1016/j.jaci.2010.10.008

4. Pajno GB, Fernandez-Rivas M, Arasi S, Roberts G, Akdis CA, Alvaro-Lozano $\mathrm{M}$, et al. EAACI Guidelines on allergen immunotherapy: IgE-mediated food allergy. Allergy (2018) 73:799-815. doi: 10.1111/all.13319

5. Renz H, Allen KJ, Sicherer SH, Sampson HA, Lack G, Beyer K, et al. Food allergy. Nat Rev Dis Primers (2018) 4:17098. doi: 10.1038/nrdp.2017.98

6. Bute JJ, Broome SB, Marcus JN, Mikulcik S, Vickery B. Development of a patient-centric food allergy research program: a model for action. Allergy (2018) 73:1551-3. doi: 10.1111/all.13452

7. Lødrup Carlsen KC, Rehbinder EM, Skjerven HO, Carlsen MH, Fatnes TA, Fugelli P, et al. Preventing atopic dermatitis and aLLergies in children - the PreventADALL study. Allergy (2018) 73:2063-70. doi: 10.1111/all.13468

8. Savage J, Johns CB. Food allergy: epidemiology and natural history. Immunol Allergy Clin North Am. (2015) 35:45-59. doi: 10.1016/j.iac.2014.09.004

9. Nwaru BI, Hickstein L, Panesar SS, Muraro A, Werfel T, Cardona V, et al. The epidemiology of food allergy in Europe: a systematic review and metaanalysis. Allergy (2014) 69:62-75. doi: 10.1111/all.12305

10. Prescott SL, Pawankar R, Allen KJ, Campbell DE, Sinn JKH, Fiocchi A, et al. A global survey of changing patterns of food allergy burden in children. World Allergy Organ J. (2013) 6:18. doi: 10.1186/1939-4551-6-21

11. Koplin JJ, Mills EN, Allen KJ. Epidemiology of food allergy and foodinduced anaphylaxis: is there really a Western world epidemic? Curr Opin Allergy Clin Immunol. (2015) 15:409-16. doi: 10.1097/ACI.000000000 0000196

12. Gupta RS, Springston EE, Warrier MR, Smith B, Kumar R, Pongracic J, et al. The prevalence, severity, and distribution of childhood food allergy in the United States. Pediatrics (2011) 128:e9-17. doi: 10.1542/peds.2011-0204 modulated by the combination of DCs, Treg cells, Breg cells, and microbiome. DCs are capable of inducing Treg cells, which produce anti-inflammatory cytokines and are able to suppress $\mathrm{T}$ effector cells. Additionally, Breg cells can produce antiinflammatory cytokines as well and can produce IgG4, which is the anti-inflammatory Ig isotype. So far food allergies are mainly managed by strict avoidance of the food allergens and can only be treated with immunotherapy. How immunotherapy exactly works is not entirely understood. Therefore, the underlying mechanisms of induction and loss of oral tolerance need to be more clearly identified so novel therapeutic treatments can be developed.

\section{AUTHOR CONTRIBUTIONS}

PS, KJ, AG, WvdV, and MA prepared the manuscript.

\section{ACKNOWLEDGMENTS}

The authors' laboratories are supported by Swiss National Science Foundation Grant No. 320030-159870, 310030_179428 and Sean Parker Asthma and Allergy Center, Stanford University USA.

13. Soller L, Ben-Shoshan M, Harrington DW, Fragapane J, Joseph L, St Pierre Y, et al. Overall prevalence of self-reported food allergy in Canada. J Allergy Clin Immunol. (2012) 130:986-8. doi: 10.1016/j.jaci.2012. 06.029

14. Dunlop JH, Keet CA. Epidemiology of food allergy. Immunol Allergy Clin North Am. (2018) 38:13-25. doi: 10.1016/j.iac.2017.09.002

15. Muraro A, Lemanske RF, Castells M, Torres MJ, Khan D, Simon HU, et al. Precision medicine in allergic disease-food allergy, drug allergy, and anaphylaxis-PRACTALL document of the European Academy of Allergy and Clinical Immunology and the American Academy of Allergy, Asthma and Immunology. Allergy (2017) 72:1006-21. doi: 10.1111/all.13132

16. Pettersson ME, Koppelman GH, Flokstra-de Blok BMJ, Kollen BJ, Dubois AEJ. Prediction of the severity of allergic reactions to foods. Allergy (2018) 73:1532-40. doi: 10.1111/all.13423

17. Pekar J, Ret D, Untersmayr E. Stability of allergens. Mol Immunol. (2018) 100:14-20. doi: 10.1016/j.molimm.2018.03.017

18. Pali-Schöll I, De Lucia M, Jackson H, Janda J, Mueller RS, JensenJarolim E. Comparing immediate-type food allergy in humans and companion animals-revealing unmet needs. Allergy (2017) 72:1643-56. doi: $10.1111 /$ all.13179

19. Bøgh KL, Madsen CB. Food allergens: is there a correlation between stability to digestion and allergenicity? Crit Rev Food Sci Nutr. (2016) 56:1545-67. doi: 10.1080/10408398.2013.779569

20. Aalberse RC. Structural biology of allergens. J Allergy Clin Immunol. (2000) 106:228-38. doi: 10.1067/mai.2000.108434

21. Beyer K, Morrow E, Li XM, Bardina L, Bannon GA, Burks AW, et al. Effects of cooking methods on peanut allergenicity. J Allergy Clin Immunol. (2001) 107:1077-81. doi: 10.1067/mai.2001.115480

22. Claude M, Bouchaud G, Lupi R, Castan L, Tranquet O, Denery-Papini S, et al. How proteins aggregate can reduce allergenicity: comparison of ovalbumins heated under opposite electrostatic conditions. J Agric Food Chem. (2017) 65:3693-701. doi: 10.1021/acs.jafc.7b00676

23. Calvani M, Arasi S, Bianchi A, Caimmi D, Cuomo B, Dondi A, et al. Is it possible to make a diagnosis of raw, heated, and baked egg allergy in children using cutoffs? A systematic review. Pediatr Allergy Immunol. (2015) 26:509-21. doi: $10.1111 /$ pai. 12432 
24. Remington BC, Westerhout J, Campbell DE, Turner PJ. Minimal impact of extensive heating of hen's egg and cow's milk in a food matrix on threshold dose-distribution curves. Allergy (2017) 72:1816-9. doi: 10.1111/all.13198

25. Perdijk O, van Splunter M, Savelkoul HFJ, Brugman S, van Neerven RJJ. Cow's milk and immune function in the respiratory tract: potential mechanisms. Front Immunol. (2018) 9:143. doi: 10.3389/fimmu.2018.00143

26. Bartuzi Z, Cocco RR, Muraro A, Nowak-Wegrzyn A. Contribution of molecular allergen analysis in diagnosis of milk allergy. Curr Allergy Asthma Rep. (2017) 17:46. doi: 10.1007/s11882-017-0716-z

27. Caubet JC, Lin J, Ahrens B, Gimenez G, Bardina L, Niggemann B, et al. Natural tolerance development in cow's milk allergic children: IgE and IgG4 epitope binding. Allergy (2017) 72:1677-85. doi: 10.1111/all.13167

28. Bloom KA, Huang FR, Bencharitiwong R, Bardina L, Ross A, Sampson HA, et al. Effect of heat treatment on milk and egg proteins allergenicity. Pediatr Allergy Immunol. (2014) 25:740-6. doi: 10.1111/pai.12283

29. Abramovitch JB, Lopata AL, O'Hehir RE, Rolland JM. Effect of thermal processing on $\mathrm{T}$ cell reactivity of shellfish allergens Discordance with IgE reactivity. PLoS ONE (2017) 12:e0173549. doi: 10.1371/journal.pone. 0173549

30. Newman EN, Firszt R. Post-transplantation development of food allergies. Curr Allergy Asthma Rep. (2018) 18:4. doi: 10.1007/s11882-018-0760-3

31. Dubois AEJ, Turner PJ, Hourihane J, Ballmer-Weber B, Beyer K, Chan $\mathrm{CH}$, et al. How does dose impact on the severity of food-induced allergic reactions, and can this improve risk assessment for allergenic foods?: report from an ILSI Europe Food Allergy Task Force Expert Group and Workshop. Allergy (2018) 73:1383-92. doi: 10.1111/all.13405

32. Chinthrajah RS, Hernandez JD, Boyd SD, Galli SJ, Nadeau KC. Molecular and cellular mechanisms of food allergy and food tolerance. J Allergy Clin Immunol. (2016) 137:984-97. doi: 10.1016/j.jaci.2016.02.004

33. Sicherer SH, Sampson HA. Food allergy: epidemiology, pathogenesis, diagnosis, and treatment. J Allergy Clin Immunol. (2014) 133:291-307. doi: 10.1016/j.jaci.2013.11.020

34. Tordesillas L, Berin MC. Mechanisms of oral tolerance. Clin Rev Allergy Immunol. (2018) 55:107-17. doi: 10.1007/s12016-018-8680-5

35. Larsen LF, Juel-Berg N, Hansen KS, Clare Mills EN, van Ree R, Poulsen LK, et al. A comparative study on basophil activation test, histamine release assay, and passive sensitization histamine release assay in the diagnosis of peanut allergy. Allergy (2018) 73:137-44. doi: 10.1111/all.13243

36. Volpicella M, Leoni C, Fanizza I, Distaso M, Leoni G, Farioli L, et al. Characterization of maize chitinase-A, a tough allergenic molecule. Allergy (2017) 72:1423-9. doi: 10.1111/all.13164

37. Miliku K, Robertson B, Sharma AK, Subbarao P, Becker AB, Mandhane PJ, et al. Human milk oligosaccharide profiles and food sensitization among infants in the CHILD Study. Allergy (2018) 73:2070-3. doi: 10.1111/all.13476

38. Palladino C, Narzt MS, Bublin M, Schreiner M, Humeniuk P, Gschwandtner $\mathrm{M}$, et al. Peanut lipids display potential adjuvanticity by triggering a proinflammatory response in human keratinocytes. Allergy (2018) 73:1746-9. doi: $10.1111 /$ all.13475

39. Schulz O, Pabst O. Antigen sampling in the small intestine. Trends Immunol. (2013) 34:155-61. doi: 10.1016/j.it.2012.09.006

40. Suzuki H, Sekine S, Kataoka K, Pascual DW, Maddaloni M, Kobayashi R, et al. Ovalbumin-protein sigma $1 \mathrm{M}$-cell targeting facilitates oral tolerance with reduction of antigen-specific CD4+ T cells. Gastroenterology (2008) 135:917-25. doi: 10.1053/j.gastro.2008.05.037

41. McDole JR, Wheeler LW, McDonald KG, Wang B, Konjufca V, Knoop KA, et al. Goblet cells deliver luminal antigen to CD103+ dendritic cells in the small intestine. Nature (2012) 483:345-9. doi: 10.1038/nature10863

42. Sutti S, Locatelli I, Bruzzì S, Jindal A, Vacchiano M, Bozzola C, et al. CX3CR1expressing inflammatory dendritic cells contribute to the progression of steatohepatitis. Clin Sci. (2015) 129:797-808. doi: 10.1042/CS20150053

43. Niess JH, Brand S, Gu X, Landsman L, Jung S, McCormick BA, et al. CX3CR1-mediated dendritic cell access to the intestinal lumen and bacterial clearance. Science (2005) 307:254-8. doi: 10.1126/science.1102901

44. Varol C, Vallon-Eberhard A, Elinav E, Aychek T, Shapira Y, Luche H, et al. Intestinal lamina propria dendritic cell subsets have different origin and functions. Immunity (2009) 31:502-12. doi: 10.1016/j.immuni.2009.06.025

45. Mazzini E, Massimiliano L, Penna G, Rescigno M. Oral tolerance can be established via gap junction transfer of fed antigens from CX3CR1(+) macrophages to CD103(+) dendritic cells. Immunity (2014) 40:248-61. doi: 10.1016/j.immuni.2013.12.012

46. Hadis U, Wahl B, Schulz O, Hardtke-Wolenski M, Schippers A, Wagner N, et al. Intestinal tolerance requires gut homing and expansion of FoxP3+ regulatory $\mathrm{T}$ cells in the lamina propria. Immunity (2011) 34:237-46. doi: 10.1016/j.immuni.2011.01.016

47. Schulz O, Jaensson E, Persson EK, Liu X, Worbs T, Agace WW, et al. Intestinal $\mathrm{CD} 103+$, but not $\mathrm{CX} 3 \mathrm{CR} 1+$, antigen sampling cells migrate in lymph and serve classical dendritic cell functions. J Exp Med. (2009) 206:3101-14. doi: 10.1084/jem.20091925

48. Bakdash G, Vogelpoel LT, van Capel TM, Kapsenberg ML, de Jong EC. Retinoic acid primes human dendritic cells to induce gut-homing, IL-10-producing regulatory T cells. Mucosal Immunol. (2015) 8:265-78. doi: $10.1038 / \mathrm{mi} .2014 .64$

49. Mucida D, Kutchukhidze N, Erazo A, Russo M, Lafaille JJ, Curotto de Lafaille MA. Oral tolerance in the absence of naturally occurring Tregs. J Clin Invest. (2005) 115:1923-33. doi: 10.1172/JCI24487

50. Curotto de Lafaille MA, Kutchukhidze N, Shen S, Ding Y, Yee $\mathrm{H}$, Lafaille JJ. Adaptive Foxp3+ regulatory $\mathrm{T}$ cell-dependent and independent control of allergic inflammation. Immunity (2008) 29:114-26. doi: 10.1016/j.immuni.2008.05.010

51. Burks AW, Laubach S, Jones SM. Oral tolerance, food allergy, and immunotherapy: implications for future treatment. J Allergy Clin Immunol. (2008) 121:1344-50. doi: 10.1016/j.jaci.2008.02.037

52. Hussey Freeland DM, Fan-Minogue H, Spergel JM, Chatila TA, Nadeau KC. Advances in food allergy oral immunotherapy: toward tolerance. Curr Opin Immunol. (2016) 42:119-23. doi: 10.1016/j.coi.2016.08.002

53. Akdis CA, Akdis M. Mechanisms of immune tolerance to allergens: role of IL-10 and Tregs. J Clin Invest. (2014) 124:4678-80. doi: 10.1172/JCI78891

54. Velaga S, Ukena SN, Dringenberg U, Alter C, Pardo J, Kershaw O, et al. Granzyme A Is required for regulatory T-cell mediated prevention of gastrointestinal graft-versus-host disease. PLoS ONE (2015) 10:e0124927. doi: 10.1371/journal.pone.0124927

55. Loebbermann J, Thornton H, Durant L, Sparwasser T, Webster KE, Sprent $\mathrm{J}$, et al. Regulatory $\mathrm{T}$ cells expressing granzyme B play a critical role in controlling lung inflammation during acute viral infection. Mucosal Immunol. (2012) 5:161-72. doi: 10.1038/mi.2011.62

56. Sakaguchi S, Yamaguchi T, Nomura T, Ono M. Regulatory T cells and immune tolerance. Cell (2008) 133:775-87. doi: 10.1016/j.cell.2008.05.009

57. Lin W, Truong N, Grossman WJ, Haribhai D, Williams CB, Wang $\mathrm{J}$, et al. Allergic dysregulation and hyperimmunoglobulinemia $\mathrm{E}$ in Foxp3 mutant mice. J Allergy Clin Immunol. (2005) 116:1106-15. doi: 10.1016/j.jaci.2005.08.046

58. Mondoulet L, Dioszeghy V, Busato F, Plaquet C, Dhelft V, Bethune K, et al. Gata3 hypermethylation and Foxp3 hypomethylation are associated with sustained protection and bystander effect following epicutaneous immunotherapy in peanut-sensitized mice. Allergy (2018) 73:2080-82. doi: 10.1111/all.13479

59. Yamashita $\mathrm{H}$, Takahashi $\mathrm{K}$, Tanaka $\mathrm{H}$, Nagai $\mathrm{H}$, Inagaki N. Overcoming food allergy through acquired tolerance conferred by transfer of Tregs in a murine model. Allergy (2012) 67:201-9. doi: 10.1111/j.1398-9995.2011.02742.x

60. Smaldini PL, Orsini Delgado ML, Fossati CA, Docena GH. Orally-induced intestinal $\mathrm{CD} 4+\mathrm{CD} 25+$ FoxP3 + Treg controlled undesired responses towards oral antigens and effectively dampened food allergic reactions. PLoS ONE (2015) 10:e0141116. doi: 10.1371/journal.pone.0141116

61. Krogulska A, Borowiec M, Polakowska E, Dynowski J, Młynarski W, Wasowska-Królikowska K. FOXP3, IL-10, and TGF-beta genes expression in children with IgE-dependent food allergy. J Clin Immunol. (2011) 31:205-15. doi: 10.1007/s10875-010-9487-1

62. Krogulska A, Polakowska E, Wasowska-Królikowska K, Małachowska B, Młynarski W, Borowiec M. Decreased FOXP3 mRNA expression in children with atopic asthma and IgE-mediated food allergy. Ann Allergy Asthma Immunol. (2015) 115:415-21. doi: 10.1016/j.anai.2015. 08.015

63. Dang TD, Allen KJ, J Martino D, Koplin JJ, Licciardi PV, Tang ML. Food-allergic infants have impaired regulatory T-cell responses following in vivo allergen exposure. Pediatr Allergy Immunol. (2016) 27:35-43. doi: 10.1111/pai.12498 
64. Masthoff LJN, Pasmans SGMA, van Doorn H, den Hartog Jager CF, Geneugelijk K, Knol EF, et al. Major hazelnut and peanut allergens are potent in basophil activation and cross-react at T cell level. Allergy (2018) 73:2080-2. doi: 10.1111/all.13498

65. Heeringa JJ, Rijvers L, Arends NJ, Driessen GJ, Pasmans SG, van Dongen JJM, et al. IgE-expressing memory B cells and plasmablasts are increased in blood of children with asthma, food allergy, and atopic dermatitis. Allergy (2018) 73:1331-6. doi: 10.1111/all.13421

66. Smith M, Tourigny MR, Noakes P, Thornton CA, Tulic MK, Prescott SL. Children with egg allergy have evidence of reduced neonatal $\mathrm{CD} 4(+) \mathrm{CD} 25(+) \mathrm{CD} 127(\mathrm{lo} /-)$ regulatory $\mathrm{T}$ cell function. J Allergy Clin Immunol. (2008) 121:1460-6, 1466 e1-7. doi: 10.1016/j.jaci.2008.03.025

67. Syed A, Garcia MA, Lyu SC, Bucayu R, Kohli A, Ishida S, et al. Peanut oral immunotherapy results in increased antigen-induced regulatory T-cell function and hypomethylation of forkhead box protein 3 (FOXP3). J Allergy Clin Immunol. (2014) 133:500-10. doi: 10.1016/j.jaci.2013.12.1037

68. Varshney P, Jones SM, Scurlock AM, Perry TT, Kemper A, Steele P, et al. A randomized controlled study of peanut oral immunotherapy: clinical desensitization and modulation of the allergic response. J Allergy Clin Immunol. (2011) 127:654-60. doi: 10.1016/j.jaci.2010.12.1111

69. Bonnet B, Vigneron J, Levacher B, Vazquez T, Pitoiset F, Brimaud F, et al. Low-dose IL-2 induces regulatory T cell-mediated control of experimental food allergy. J Immunol. (2016) 197:188-98. doi: 10.4049/jimmunol.1501271

70. Smaldini PL, Trejo F, Cohen JL, Piaggio E, Docena GH. Systemic IL-2/antiIL-2Ab complex combined with sublingual immunotherapy suppresses experimental food allergy in mice through induction of mucosal regulatory T cells. Allergy (2018) 73:885-95. doi: 10.1111/all.13402

71. Tordesillas L, Mondoulet L, Blazquez AB, Benhamou PH, Sampson HA, Berin MC. Epicutaneous immunotherapy induces gastrointestinal LAP $(+)$ regulatory $\mathrm{T}$ cells and prevents food-induced anaphylaxis. J Allergy Clin Immunol. (2017) 139:189-201 e4. doi: 10.1016/j.jaci.2016.03.057

72. Vonk MM, Diks MAP, Wagenaar L, Smit JJ, Pieters RHH, Garssen J, et al. Improved efficacy of oral immunotherapy using non-digestible oligosaccharides in a murine cow's milk allergy model: a potential role for Foxp3+ regulatory T cells. Front Immunol. (2017) 8:1230. doi: 10.3389/fimmu.2017.01230

73. Carrier Y, Yuan J, Kuchroo VK, Weiner HL. Th3 cells in peripheral tolerance. I. Induction of Foxp3-positive regulatory $\mathrm{T}$ cells by $\mathrm{Th} 3$ cells derived from TGF-beta T cell-transgenic mice. J Immunol. (2007) 178:179-85. doi: 10.4049/jimmunol.178.1.179

74. Tran DQ, Andersson J, Wang R, Ramsey H, Unutmaz D, Shevach EM. GARP (LRRC32) is essential for the surface expression of latent TGF-beta on platelets and activated FOXP3+ regulatory T cells. Proc Natl Acad Sci USA. (2009) 106:13445-50. doi: 10.1073/pnas.0901944106

75. Edwards JP, Hand TW, Morais da Fonseca D, Glass DD, Belkaid Y, Shevach EM. The GARP/Latent TGF-betal complex on Treg cells modulates the induction of peripherally derived Treg cells during oral tolerance. Eur J Immunol. (2016) 46:1480-9. doi: 10.1002/eji.201546204

76. Kuhn C, Rezende RM, M'Hamdi H, da Cunha AP, Weiner HL. IL-6 inhibits upregulation of membrane-bound TGF-beta 1 on CD4+ T cells and blocking IL-6 enhances oral tolerance. J Immunol. (2017) 198:1202-9. doi: 10.4049/jimmunol.1600921

77. Nakajima-Adachi H, Shibahara K, Fujimura Y, Takeyama J, Hiraide E, Kikuchi A, et al. Critical role of intestinal interleukin-4 modulating regulatory $\mathrm{T}$ cells for desensitization, tolerance, and inflammation of food allergy. PLoS ONE (2017) 12:e0172795. doi: 10.1371/journal.pone.0172795

78. Iwata M, Hirakiyama A, Eshima Y, Kagechika H, Kato C, Song SY. Retinoic acid imprints gut-homing specificity on T cells. Immunity (2004) 21:527-38. doi: 10.1016/j.immuni.2004.08.011

79. Cassani B, Villablanca EJ, Quintana FJ, Love PE, Lacy-Hulbert A, Blaner WS, et al. Gut-tropic T cells that express integrin alpha4beta7 and CCR9 are required for induction of oral immune tolerance in mice. Gastroenterology (2011) 141:2109-18. doi: 10.1053/j.gastro.2011.09.015

80. Coombes JL, Siddiqui KR, Arancibia-Cárcamo CV, Hall J, Sun CM, Belkaid $\mathrm{Y}$, et al. A functionally specialized population of mucosal CD103+ DCs induces Foxp3+ regulatory $\mathrm{T}$ cells via a TGF-beta and retinoic aciddependent mechanism. J Exp Med. (2007) 204:1757-64. doi: 10.1084/jem.20 070590
81. Bedoret D, Singh AK, Shaw V, Hoyte EG, Hamilton R, DeKruyff RH, et al. Changes in antigen-specific T-cell number and function during oral desensitization in cow's milk allergy enabled with omalizumab. Mucosal Immunol. (2012) 5:267-76. doi: 10.1038/mi.2012.5

82. Ryan JF, Hovde R, Glanville J, Lyu SC, Ji X, Gupta S, et al. Successful immunotherapy induces previously unidentified allergen-specific CD4+ T-cell subsets. Proc Natl Acad Sci USA. (2016) 113:E1286-95. doi: 10.1073/pnas. 1520180113

83. Noh G, Lee JH. Regulatory B cells and allergic diseases. Allergy Asthma Immunol Res. (2011) 3:168-77. doi: 10.4168/aair.2011.3.3.168

84. Rosser EC, Mauri C. Regulatory B cells: origin, phenotype, and function. Immunity (2015) 42:607-12. doi: 10.1016/j.immuni.2015.04.005

85. van de Veen W, Stanic B, Wirz OF, Jansen K, Globinska A, Akdis M. Role of regulatory B cells in immune tolerance to allergens and beyond. J Allergy Clin Immunol. (2016) 138:654-65. doi: 10.1016/j.jaci.2016.07.006

86. van de Veen W, Stanic B, Yaman G, Wawrzyniak M, Söllner S, Akdis DG, et al. IgG4 production is confined to human IL-10-producing regulatory B cells that suppress antigen-specific immune responses. J Allergy Clin Immunol. (2013) 131:1204-12. doi: 10.1016/j.jaci.2013.01.014

87. Santos AF, James LK, Bahnson HT, Shamji MH, Couto-Francisco NC, Islam $\mathrm{S}$, et al. IgG4 inhibits peanut-induced basophil and mast cell activation in peanut-tolerant children sensitized to peanut major allergens. J Allergy Clin Immunol. (2015) 135:1249-56. doi: 10.1016/j.jaci.2015.01.012

88. Stanic B, van de Veen W, Wirz OF, Rückert B, Morita H, Söllner S, et al. IL10 -overexpressing B cells regulate innate and adaptive immune responses. $J$ Allergy Clin Immunol. (2015) 135:771-80.e8. doi: 10.1016/j.jaci.2014.07.041

89. Komlósi ZI, Kovács N, van de Veen W, Kirsch AI, Fahrner HB, Wawrzyniak $\mathrm{M}$, et al. Human CD40 ligand-expressing type 3 innate lymphoid cells induce IL-10-producing immature transitional regulatory B cells. J Allergy Clin Immunol. (2017) 142:178-94.e11. doi: 10.1016/j.jaci.2017.07.046

90. Kim AR, Kim HS, Kim DK, Nam ST, Kim HW, Park YH, et al. Mesenteric IL10-producing CD5+ regulatory B cells suppress cow's milk casein-induced allergic responses in mice. Sci Rep. (2016) 6:19685. doi: 10.1038/srep19685

91. Hoh RA, Joshi SA, Liu Y, Wang C, Roskin KM, Lee JY, et al. Single B-cell deconvolution of peanut-specific antibody responses in allergic patients. $J$ Allergy Clin Immunol. (2016) 137:157-67. doi: 10.1016/j.jaci.2015.05.029

92. Shaker M, Stukus D, Chan ES, Fleischer DM, Spergel JM, Greenhawt M, et al. "To screen or not to screen": comparing the health and economic benefits of early peanut introduction strategies in five countries. Allergy (2018) 73:1707-14. doi: 10.1111/all.13446

93. Mielle J, Audo R, Hahne M, Macia L, Combe B, Morel J, et al. IL-10 producing $\mathrm{B}$ cells ability to induce regulatory $\mathrm{T}$ cells is maintained in rheumatoid arthritis. Front Immunol. (2018) 9:961. doi: 10.3389/fimmu.2018.00961

94. Huang X, Tsilochristou O, Perna S, Hofmaier S, Cappella A, Bauer CP, et al. Evolution of the $\operatorname{IgE}$ and $\operatorname{IgG}$ repertoire to a comprehensive array of allergen molecules in the first decade of life. Allergy (2018) 73:421-30. doi: 10.1111/all.13269

95. Karlsson MR, Johansen FE, Kahu H, Macpherson A, Brandtzaeg P. Hypersensitivity and oral tolerance in the absence of a secretory immune system. Allergy (2010) 65:561-70. doi: 10.1111/j.1398-9995.2009.02225.x

96. Ho HE, Bunyavanich S. Role of the microbiome in food allergy. Curr Allergy Asthma Rep. (2018) 18:27. doi: 10.1007/s11882-018-0780-z

97. Lynch SV, Pedersen O. The human intestinal microbiome in health and disease. N Engl J Med. (2016) 375:2369-79. doi: 10.1056/NEJMra1600266

98. Bjerre RD, Bandier J, Skov L, Engstrand L, Johansen JD. The role of the skin microbiome in atopic dermatitis: a systematic review. Br J Dermatol. (2017) 177:1272-8. doi: 10.1111/bjd.15390

99. Arrieta MC, Stiemsma LT, Dimitriu PA, Thorson L, Russell S, YuristDoutsch S, et al. Early infancy microbial and metabolic alterations affect risk of childhood asthma. Sci Transl Med. (2015) 7:307ra152. doi: 10.1126/scitranslmed.aab2271

100. Ashley SE, Tan HT, Vuillermin P, Dharmage SC, Tang MLK, Koplin J, et al. The skin barrier function gene SPINK5 is associated with challengeproven IgE-mediated food allergy in infants. Allergy (2017) 72:1356-64. doi: $10.1111 /$ all.13143

101. Kawasaki A, Ito N, Murai H, Yasutomi M, Naiki H, Ohshima Y. Skin inflammation exacerbates food allergy symptoms in epicutaneously sensitized mice. Allergy (2018) 73:1313-21. doi: 10.1111/all.13404 
102. Lawson K, Bahnson HT, Brittain E, Sever M, Du Toit G, Lack G, et al. Letter of response to Greenhawt et al. "LEAPing through the looking glass: secondary analysis of the effect of skin test size and age of introduction on peanut tolerance after early peanut introduction". Allergy (2017) 72:1267-71. doi: 10.1111/all.13127

103. Marrs T, Sim K. Demystifying dysbiosis: can the gut microbiome promote oral tolerance over IgE-mediated food allergy? Curr Pediatr Rev. (2018) 14:156-63. doi: 10.2174/1573396314666180507120424

104. Barratt MJ, Lebrilla C, Shapiro HY, Gordon JI. The gut microbiota, food science, and human nutrition: a timely marriage. Cell Host Microbe (2017) 22:134-41. doi: 10.1016/j.chom.2017.07.006

105. Diesner SC, Bergmayr C, Pfitzner B, Assmann V, Krishnamurthy D, Starkl P, et al. A distinct microbiota composition is associated with protection from food allergy in an oral mouse immunization model. Clin Immunol. (2016) 173:10-18. doi: 10.1016/j.clim.2016.10.009

106. Lyons A, O'Mahony D, O'Brien F, MacSharry J, Sheil B, Ceddia M, et al. Bacterial strain-specific induction of Foxp3 $+\mathrm{T}$ regulatory cells is protective in murine allergy models. Clin Exp Allergy (2010) 40:811-9. doi: 10.1111/j.1365-2222.2009.03437.x

107. Konieczna P, Ferstl R, Ziegler M, Frei R, Nehrbass D, Lauener RP, et al. Immunomodulation by Bifidobacterium infantis 35624 in the murine lamina propria requires retinoic acid-dependent and independent mechanisms. PLoS ONE (2013) 8:e62617. doi: 10.1371/journal.pone.0062617

108. Konieczna P, Schiavi E, Ziegler M, Groeger D, Healy S, Grant R, et al. Human dendritic cell DC-SIGN and TLR-2 mediate complementary immune regulatory activities in response to Lactobacillus rhamnosus JB-1. PLoS ONE (2015) 10:e0120261. doi: 10.1371/journal.pone.0120261

109. Kraal L, Abubucker S, Kota K, Fischbach MA, Mitreva M. The prevalence of species and strains in the human microbiome: a resource for experimental efforts. PLoS ONE (2014) 9:e97279. doi: 10.1371/journal.pone.0097279

110. Dzidic M, Abrahamsson TR, Artacho A, Collado MC, Mira A, Jenmalm MC. Oral microbiota maturation during the first 7 years of life in relation to allergy development. Allergy (2018) 73:2000-11. doi: 10.1111/all.13449

111. Elbert NJ, van Meel ER, den Dekker HT, de Jong NW, Nijsten TEC, Jaddoe VWV, et al. Duration and exclusiveness of breastfeeding and risk of childhood atopic diseases. Allergy (2017) 72:1936-43. doi: 10.1111/all.13195

112. Rodriguez B, Prioult G, Bibiloni R, Nicolis I, Mercenier A, Butel MJ, et al. Germ-free status and altered caecal subdominant microbiota are associated with a high susceptibility to cow's milk allergy in mice. FEMS Microbiol Ecol. (2011) 76:133-44. doi: 10.1111/j.1574-6941.2010.01035.x

113. Noval Rivas M, Burton OT, Wise P, Zhang YQ, Hobson SA, Garcia Lloret $\mathrm{M}$, et al. A microbiota signature associated with experimental food allergy promotes allergic sensitization and anaphylaxis. J Allergy Clin Immunol. (2013) 131:201-12. doi: 10.1016/j.jaci.2012.10.026

114. Noval Rivas M, Burton OT, Wise P, Charbonnier LM, Georgiev P, Oettgen $\mathrm{HC}$, et al. Regulatory $\mathrm{T}$ cell reprogramming toward a Th2-cell-like lineage impairs oral tolerance and promotes food allergy. Immunity (2015) 42:51223. doi: 10.1016/j.immuni.2015.02.004

115. van Ginkel CD, Pettersson ME, Dubois AEJ, Koppelman GH. Association of STAT6 gene variants with food allergy diagnosed by double-blind placebocontrolled food challenges. Allergy (2018) 73:1337-41. doi: 10.1111/all.13432

116. Ohnmacht C, Park JH, Cording S, Wing JB, Atarashi K, Obata Y, et al. MUCOSAL IMMUNOLOGY. The microbiota regulates type 2 immunity through RORgammat(+) T cells. Science (2015) 349:989-93. doi: $10.1126 /$ science.aac4263

117. Frei R, Lauener RP, Crameri R, O’Mahony L. Microbiota and dietary interactions: an update to the hygiene hypothesis? Allergy (2012) 67:451-61. doi: 10.1111/j.1398-9995.2011.02783.x

118. Sørensen M, Klingenberg C, Wickman M, Sollid JUE, Furberg AS, Bachert $\mathrm{C}$, et al. Staphylococcus aureus enterotoxin sensitization is associated with allergic poly-sensitization and allergic multimorbidity in adolescents. Allergy (2017) 72:1548-55. doi: 10.1111/all.13175

119. Tan J, McKenzie C, Potamitis M, Thorburn AN, Mackay CR, Macia L. The role of short-chain fatty acids in health and disease. Adv Immunol. (2014) 121:91-119. doi: 10.1016/B978-0-12-800100-4.00003-9

120. Grimshaw KE, Maskell J, Oliver EM, Morris RC, Foote KD, Mills EN, et al. Diet and food allergy development during infancy: birth cohort study findings using prospective food diary data. J Allergy Clin Immunol. (2014) 133:511-9. doi: 10.1016/j.jaci.2013.05.035

121. Zhang Z, Shi L, Pang W, Liu W, Li J, Wang H, et al. Dietary fiber intake regulates intestinal microflora and inhibits ovalbumin-induced allergic airway inflammation in a mouse model. PLoS ONE (2016) 11:e0147778. doi: 10.1371/journal.pone.0147778

122. Costantini L, Molinari R, Farinon B, Merendino N. Impact of omega3 fatty acids on the gut microbiota. Int J Mol Sci. (2017) 18:E2645. doi: 10.3390/ijms18122645

123. Lee-Sarwar K, Kelly RS, Lasky-Su J, Kachroo P, Zeiger RS, O’Connor GT, et al. Dietary and plasma polyunsaturated fatty acids are inversely associated with asthma and atopy in early childhood. J Allergy Clin Immunol Pract. (2018). doi: 10.1016/j.jaip.2018.07.039. [Epub ahead of print].

124. Barcik W, Wawrzyniak M, Akdis CA, O’Mahony L. Immune regulation by histamine and histamine-secreting bacteria. Curr Opin Immunol. (2017) 48:108-13. doi: 10.1016/j.coi.2017.08.011

125. Ferstl R, Frei R, Schiavi E, Konieczna P, Barcik W, Ziegler M, et al. Histamine receptor 2 is a key influence in immune responses to intestinal histamine-secreting microbes. J Allergy Clin Immunol. (2014) 134:744-6.e3. doi: 10.1016/j.jaci.20break14.04.034

126. Smolinska S, Jutel M, Crameri R, O’Mahony L. Histamine and gut mucosal immune regulation. Allergy (2014) 69:273-81. doi: 10.1111/all.12330

127. Barcik W, Pugin B, Westermann P, Perez NR, Ferstl R, Wawrzyniak $\mathrm{M}$, et al. Histamine-secreting microbes are increased in the gut of adult asthma patients. $J$ Allergy Clin Immunol. (2016) 138:1491-4.e7. doi: 10.1016/j.jaci.2016. 05.049

Conflict of Interest Statement: The authors declare that the research was conducted in the absence of any commercial or financial relationships that could be construed as a potential conflict of interest.

Copyright (c) 2018 Satitsuksanoa, Jansen, Głobinska, van de Veen and Akdis. This is an open-access article distributed under the terms of the Creative Commons Attribution License (CC BY). The use, distribution or reproduction in other forums is permitted, provided the original author(s) and the copyright owner(s) are credited and that the original publication in this journal is cited, in accordance with accepted academic practice. No use, distribution or reproduction is permitted which does not comply with these terms. 